\title{
PENGARUH STRATEGI EXPERIENTIAL LEARNING TERHADAP SELF REGULATED LEARNING MAHASISWA
}

\author{
Eva Latipah \\ Fakultas Ilmu Tarbiyah dan Keguruan Universitas Islam Negeri (UIN) \\ Sunan Kalijaga. \\ Jalan Marsda Adi Sucipto, Yogyakarta 55221 \\ evalatipah@yahoo.co.id
}

\begin{abstract}
Self regulated learning has a very important role on many aspects of life, especially academic field. This study aimed to examine effect of experiential learning strategies to students self-regulated learning and its components (learning motivation, learning strategies cognitive, metacognitive regulation, and manage resources). Subjects were 40 in experimental group and 40 in control group. Instruments used in data collection is self regulated learning scale and experiential learning modules are used as a guideline in applying experiential learning strategy. Multivariate analysis techniques are used to analyze data. Results show that there are significant differences of self regulated learning, learning motivation, cognitive learning strategies, metacognitive regulation, and manage resources between experimental and control groups. This means that experiential learning strategies can improve student self-regulated learning.
\end{abstract}

Keywords: experiential learning, learning motivation, metacognitive regulation, self regulated learning

\begin{abstract}
Abstrak
Self regulated learning memiliki peranan yang sangat penting terhadap banyak aspek kehidupan terutama bidang akademik. Penelitian ini bertujuan untuk menguji pengaruh strategi experiential learning terhadap self regulated learning dan komponenkomponennya (motivasi belajar, strategi belajar kognitif, regulasi metakognitif, dan kelola sumber daya) mahasiswa. Subjek penelitian ini adalah 40 orang kelompok eksperimen dan 40 orang kelompok kontrol. Instrumen yang digunakan dalam pengumpulan data adalah skala self regulated learning dan modul experiential learning digunakan sebagai pedoman dalam menerapkan strategi pembelajaran eksperiensial. Teknik analisis multivariat digunakan untuk menganalisis data. Hasil menunjukkan bahwa ada perbedaan self regulated learning, motivasi belajar, , metacognitive regulation, dan kelola sumber daya yang signifikan antara kelompok eksperimen dan kelompok kontrol. Ini artinya bahwa strategi experiential learning mampu meningkatkan self regulated learning mahasiswa.
\end{abstract}

Kata kunci: experiential learning, metacognitive regulation, motivasi belajar, self regulated learning 


\section{Pendahuluan}

Mahasiswa sebagai individu yang memasuki tahap dewasa awal berada dalam tahap kognitif post formal thought yaitu cara berpikir yang fleksibel, terbuka, adaptif, dan individualistik (Piaget, dalam Santrock, 1997). Cara berpikir ini biasanya ditandai dengan kemampuan untuk menghadapi ketidakpastian, ketidakstabilan, sesuatu yang kontradiktif, ketidaksempurnaan, dan berkompromi; bahkan kemampuan metakognisi mahasiswa dipandang lebih baik dibandingkan dengan pada level sebelumnya (Pintrich \& DeGroot 1990). Menurut Santrock (1997), karakteristik masa dewasa yang berkaitan dengan proses pembelajaran adalah masa pengaturan (settle down), masa ketegangan emosional, masa komitmen, masa perubahan nilai, dan masa penyesuaian diri dengan kehidupan baru. Ini menunjukkan bahwa mahasiswa dituntut harus lebih bertanggungjawab dan harus melepaskan ketergantungannya menuju kemandirian untuk menjalankan peran dan tugas-tugas barunya yang sesuai dengan harapannya, termasuk tugas-tugas baru terkait pembelajarannya.

Kondisi ini berdampak pada bagaimana pembelajaran mahasiswa sebagai individu yang memasuki tahap dewasa. Menurut Knowles (1970) pembelajaran orang dewasa memiliki karakteristik: pertumbuhan dan kematangan konsep diri bergerak dari ketergantungan total menuju ke arah pengarahan diri sendiri (self directed), mengumpulkan sejumlah besar pengalaman, dan berkecenderungan memiliki orientasi belajar yang berpusat pada pemecahan masalah kehidupan (problem centeredorientation). Konsekuensi dalam pembelajaran di kelas, penyampaian materi perlu menggunakan pendekatan yang mendukung pada pencapaian self directed mahasiswa, menjadikan pengalaman sebagai sumber pembelajaran, dan mengarahkan orientasi belajar pada pemecahan masalah kehidupan sehari-hari.

Belajar di Perguruan Tinggi menuntut mahasiswa untuk belajar lebih mandiri, disiplin dalam mengatur waktu, dan melaksanakan kegiatan belajar yang lebih terarah dan intensif sehingga memungkinkan mahasiswa tampil produktif, kreatif, dan inovatif (Laurillard, 2002). Untuk belajar secara mandiri mahasiswa harus menjadi seorang pembelajar dengan mengatur pembelajarannya sendiri (Woolfolk, 2008). Bekal utama yang dibutuhkan mahasiswa untuk menyesuaikan diri dengan keadaan tersebut adalah memiliki kemampuan dan keterampilan untuk mengatur kegiatan belajar, mengontrol perilaku belajar, dan mengetahui tujuan, arah, serta sumber-sumber yang mendukung untuk belajarnya (Ormrod, 2008).

Self regulated learning menempatkan pentingnya kemampuan seseorang untuk belajar disiplin, mengatur, dan mengendalikan diri sendiri terutama bila menghadapi tugas-tugas yang sulit. Dalam hal belajar, mahasiswa yang sudah mengetahui secara pasti tujuan kegiatan belajarnya akan mengarahkan segala pemikiran, perasaan, penerapan starategi, dan tingkah lakunya untuk mencapai tujuan yang telah ditetapkan dan mempertahankan prestasi akademiknya (Paris \& Turner, 1994). Mahasiswa dikatakan telah menerapkan self regulated learning apabila memiliki strategi untuk mengaktifkan metakognisi, motivasi, dan tingkah laku dalam proses belajarnya (Zimmerman dan Martinez-Ponz, 1990). Kebiasaan mengatur dan mengarahkan diri sendiri diharapkan dapat terbentuk dalam diri mahasiswa. Hal ini mengindikasikan bahwa self regulated learning menekankan pentingnya inisiatif karena ia merupakan belajar yang terjadi atas inisiatif. Mahasiswa yang memiliki inisiatif menunjukkan kemampuan untuk mempergunakan pemikiran-pemikirannya, perasaan-perasaannya, 
strategi dan tingkah lakunya yang ditunjukkan untuk mencapai tujuan (Zimmerman, 2002).

Zimmerman dan Martinez-Pons (2001) mendefinisikan self regulated learning sebagai tingkatan seseorang yang secara aktif melibatkan metakognisi, motivasi, dan perilaku dalam proses belajar. Self regulated learning menggarisbawahi pentingnya otonomi dan tanggung jawab pribadi dalam kegiatan belajar. Seorang self regulated learner membangun tujuan-tujuan belajar, mencoba memonitor, meregulasi, dan mengontrol kognisi, motivasi, dan perilakunya untuk mengontrol tujuan-tujuan yang telah dibuat (Valle,dkk., 2008). Seorang self regulated learner memiliki kombinasi keterampilan belajar akademik dan pengendalian diri yang membuat pembelajarannya terasa lebih mudah, sehingga mereka lebih termotivasi. Dengan kata lain mereka memiliki keterampilan (skill) dan kemauan (will) untuk belajar (Murphy \& Alexander, 2000). Seorang self regulated learner juga mentransformasikan kemampuankemampuan mental mereka menjadi keterampilan-keterampilan dan strategi-strategi akademik (Zimmerman, 2002).

Sejumlah penelitian seperti dilakukan Sawitri \& Ariati (2010), Latipah (2009), Darmiany (2009), Sunawan (2003) menunjukkan bahwa mahasiswa nampak masih belum menghayati kebiasaan belajar di Perguruan Tinggi dan belum dapat menyesuaikan diri dengan kehidupan kampus. Rosiana (2010) dan Arjanggi \& Suprihatin (2010) menemukan bahwa masih banyak mahasiswa yang self regulated learningnya rendah yang ditunjukkan dalam rendahnya tanggungjawab personal terhadap materi yang dipelajari. Dengan tanggungjawab personal yang rendah mengakibatkan mahasiswa merasa kesulitan ketika ujian; akhirnya merekapun mencontek saja. Mahasiswa lebih senang menggunakan jalan pintas dalam menghadapi ujian atau tesnya dengan cara mencontek daripada harus dengan cara belajar giat. Ini diperkuat hasil survey Davis (2009) terhadap mahasiswa di perguruan tinggi swasta yang menemukan bahwa 95\% (dari 600 orang) mahasiswa mengaku pernah mencontek, dan frekuensi mencontek mereka di atas lima kali. Penelitian Latipah (2009) terhadap mahasiswa program studi PGMI Fakultas Ilmu Tarbiyah UIN Sunan Kalijaga ditemukan bahwa mereka masih memiliki self regulated learning rendah yang ditunjukkan dalam tanggung jawab personal, kurang mengontrol pengetahuan dan keterampilan-keterampilan, tidak mempunyai keinginan untuk menggunakan strategistrategi belajar kognitif.

Motivasi merupakan hal esensial dalam SRL karena melalui motivasi seseorang mau mengambil tindakan dan tanggung jawab atas kegiatan belajar yang dilakukan (Smith, 2001). Motivasi biasa diartikan sebagai keadaan internal yang membangkitkan, mengarahkan, dan mempertahankan perilaku (Woolfolk, 2008). Motivasi dalam SRL diwujudkan dalam bentuk pembuatan keputusan untuk berpartisipasi (Zimmerman dalam Elliot, dkk., 1999).

Proses-proses regulasi diri (self regulatory process) yang dapat meningkatkan motivasi dalam SRL meliputi efikasi diri (self efficacy), tujuan pribadi (self goals), nilai, dan atribusi. Efikasi diri (self efficacy) mengacu pada keyakinan (belief) mahasiswa bahwa dia dapat mengadakan beberapa kontrol pada suatu peristiwa yang mempengaruhi kehidupannya (Bandura, 1997). Tujuan (goals) membimbing usaha mahasiswa untuk bertindak dalam arah tertentu dan berguna sebagai kriteria untuk evaluasi diri (Schwartz \& Gredler dalam Smith, 2001). Orientasi tujuan ada dua jenis yaitu orientasi tujuan belajar dan orientasi tujuan kinerja (Dweck, 1999). Individu dengan orientasi tujuan belajar ditandai dengan keyakinan bahwa kompetensi dapat 
dikembangkan, menilai kompetensi dalam kaitannya dengan kemampuan sebelumnya, dan memilih serta bertahan pada tuntutan tugas. Individu dengan orientasi tujuan kinerja ditandai dengan keyakinan bahwa kompetensi itu tidak mudah diubah atau dikembangkan, mengevaluasi kompetensinya dalam kaitannya dengan kompetensi orang lain; dan memilih tugas yang mana dia bisa mengembangkan kompetensinya dan menghindari kegagalan. Berbagai penelitian menunjukkan bahwa seseorang dengan orientasi tujuan belajar memiliki motivasi yang lebih tinggi daripada seseorang dengan orientasi tujuan kinerja (Barron \& Harackiewics, 2001). Seorang self regulated learner lebih berfokus pada orientasi tujuan belajar dan bukannya berorientasi tujuan kinerja (Smith, 2001).

Sejumlah ahli menggunakan istilah metode belajar untuk menunjukkan strategi belajar (learning startegies) dalam self regulated learning. Persyaratan tugas dari dimensi metode adalah memilih metode yang tepat untuk meningkatkan kualitas belajarnya (Zimmerman dalam Elliot, dkk., 1999). Atribut regulasi diri dari komponen metode adalah terjadinya perilaku mahasiswa yang menjadi terencana dan terotomatisasi. Dikatakan terencana karena perilaku mahasiswa yang melaksanakan belajar berdasar regulasi diri memiliki tujuan dan kesadaran diri yang jelas. Dikatakan terotomatisasi karena penggunaan metode belajar yang tepat dan dilakukan secara berulang-ulang menjadi kebiasaan bagi dirinya. Strategi belajar kognitif dalam SRL meliputi latihan (rehearsing), perluasan materi (elaborating), model (modelling), dan pengaturan (organizing) (Smith, 2001).

Seorang self regulated learner memiliki kesadaran terhadap hasil kinerjanya (Zimmerman \& Kitsantas, 1999). Ada dua hal yang perlu dicermati berkaitan dengan metakognisi yaitu pengetahuan dan regulasi metakognitif (Woolfolk, 2008). Pengetahuan metakognisi menunjuk pada pengetahuan mahasiswa tentang kemampuan kognitif yang dimiliki. Ini terdiri dari tiga sub-pengetahuan yang memfasilitasi aspek refleksi metakognisi yakni pengetahuan deklaratif, pengetahuan prosedural, dan pengetahuan kondisional (Bruning, dkk., 2004).

Regulasi metakognitif berkaitan dengan mekanisme regulasi diri. Regulasi metakognitif meliputi sejumlah sub-proses yang memfasilitasi aspek kontrol dalam belajar seperti perencanaan, pemantauan, dan penilaian yang digunakan mahasiswa dalam aktivitas belajar (Woolfolk, 2008; Slavin, 2009). Regulasi metakognitif dengan kata lain menerapkan pengetahuan metakognitif yang digunakan untuk meregulasi pemikiran dan pembelajaran (Nelson, 1996). Keterampilan mendasar yang dilakukan dalam hal ini meliputi: perencanaan, pengontrolan, dan penilaian (Zimmerman \& Martinez-Pons, 1998).

Seorang sef regulated learner memiliki sensitivitas terhadap lingkungan sosial dan sumber daya (resource) yang terdapat di sekitarnya. Zimmerman (dalam Smith, 2006) menggunakan istilah 'resourcefullness' yang mengacu pada kemampuan untuk mengontrol lingkungan fisik di sekitarnya dalam hal membatasi distraksi yang mengganggu kegiatan belajar, dan secara sukses mencari dan menggunakan referensi serta keahlian yang diperlukan untuk menguasai apa yang dipelajari. Resourcefullness ditandai dengan adanya keaktifan seseorang dalam mencari informasi, mengorganisir lingkungan, dan meminimalisir distraktor (Zimmerman \& Martinez-Pons dalam Smith, 2006). Bentuk proses regulasi diri yang berkaitan dengan dimensi lingkungan adalah menstruktur lingkungan (environmental structuring) dan mencari bantuan (help seeking) (Zimmerman \& Martinez-Pons, 1998). Menstruktur lingkungan berkaitan dengan menciptakan lingkungan belajar yang dapat mendukung terlaksananya kegiatan 
belajar secara optimal. Seorang self regulated learner tidak selalu menguasai materi secara sempurna. Oleh karenanya, ia perlu mencari bantuan (help seeking) kepada orang lain dan sumber-sumber lainnya.

Meningkatkan self regulated learning dapat dilakukan dengan berbagai cara di antaranya adalah dengan memberikan tugas yang kompleks (Woolfolk, 2008). Pemberian tugas kompleks dapat dilakukan dengan menggunakan beragam metode seperti metode realistik, metode bermain peran, metode praktek, uji coba, bereksperimen. Metode-metode tersebut merupakan bagian dari strategi experiential learning (Saskatchwan Education, 1988).

Individu yang 'ahli' dalam meregulasi diri melakukan sebuah siklus yang terdiri dari 3 tahapan yaitu tahap pemikiran ke masa depan (forethought phase), tahap performansi atau mengontrol kemauan (performance or volitional control phase), dan tahap meregulasi belajar atau refleksi diri (regulated learning or self-reflection phase) (Zimmerman \& Martinez-Pons, 1998). Untuk melalui tahapan-tahapan dalam self regulated learning diri diperlukan strategi atau metode pembelajaran yang tepat. Diantara tahapan yang penting adalah tahapan refleksi. Tahapan refleksi dipentingkan untuk mengevaluasi kegiatan apa saja yang telah dilakukan dan bagaimana hasil yang diperoleh. Experiential learning merupakan sebuah strategi pembelajaran yang sangat menekankan pentingnya refleksi. Refleksi dalam self regulated learning dilakukan dengan mengevaluasi dirinya (self evaluation) yaitu melihat kembali kinerjanya dan merefleksikan apa yang terjadi.

Experiential learning dilandasi oleh teori konstruktivisme (Bruning, dkk., 2004). Konstruktivisme memandang belajar lebih dari sekedar menerima dan memproses informasi yang disampaikan oleh pengajar (dosen, guru) atau buku teks. Lebih dari itu, pembelajaran adalah konstruksi pengetahuan yang bersifat aktif dan personal (De Kock, dkk., 2004). Experiential learning merupakan proses dimana pengetahuan diciptakan melalui transformasi pengalaman. Pengetahuan merupakan hasil perpaduan antara memahami dan mentransformasi pengalaman (Kolb, 1984). Dalam proses pembelajaran mahasiswa terlibat secara aktif, berpikir tentang apa yang dipelajari, dan kemudian bagaimana menerapkan apa yang telah dipelajari dalam situasi nyata (Marcus, dkk., 1996).

Experiential learning memiliki tiga aspek penting yaitu pengetahuan (konsep, fakta, informasi), aktivitas (penerapan dalam kegiatan), dan refleksi (analisis dampak kegiatan terhadap perkembangan individu). Ketiganya merupakan kontribusi penting dalam tercapainya tujuan pembelajaran (Kolb, 1984). Dalam upaya mengubah aspek kognitif, sikap, dan memperluas keterampilan mahasiswa melalui pengalaman dilakukan dengan menempuh tahapan-tahapan dalam experiential learning yaitu concrete experience, reflective observation, abstract conceptualization, dan experiment. Keempat tahapan ini membentuk sebuah siklus sebagaimana ditunjukkan pada Gambar 1. 


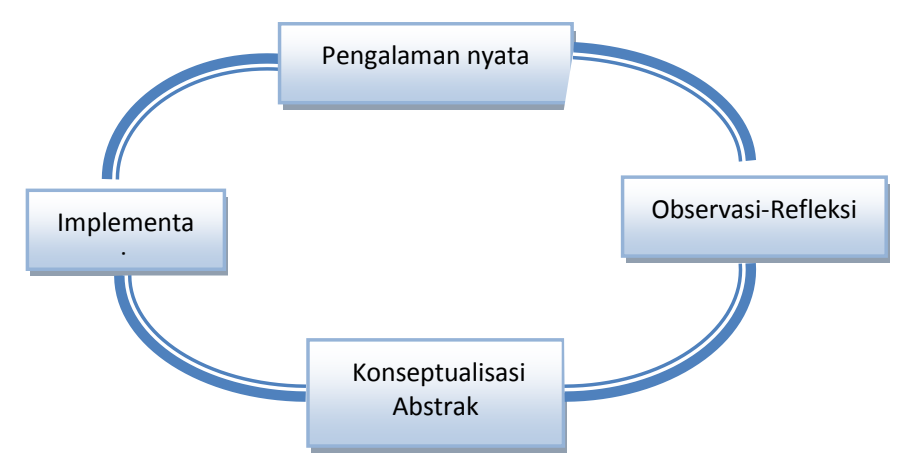

Gambar 1. Siklus Experiential Learning

Sumber: Kolb, dalam Seamen, (2008). Experience, reflect, critique: The end of the learning cycles era, hal. 5.

Pada tahap pengalaman konkrit, belajar dimulai dari sebuah pengalaman konkrit yang dialami mahasiswa. Pada tahap observasi-refleksi mahasiswa mengamati pengalaman dari aktivitas belajar yang dilakukan dengan menggunakan panca indera maupun dengan bantuan alat peraga. Pada tahap konseptualisasi abstrak mahasiswa mulai mencari alasan dan merumuskan hubungan timbal balik dari pengalaman yang diperolehnya. Tahap implementasi mahasiswa merencanakan bagaimana menguji keampuhan model atau teori untuk menjelaskan pengalaman baru yang akan diperoleh selanjutnya.

Dengan mengalami dan merefleksikan materi dalam setiap pembelajaran sangat memungkinkan mahasiswa untuk mampu meregulasi pembelajarannya sendiri. Oleh karena itu perlu dikaji lebih lanjut apakah ada pengaruh strategi experiential learning terhadap self regulated learning mahasiswa PGMI Fakultas Ilmu Tarbiyah dan Keguruan UIN Sunan Kalijaga.

\section{Metode Penelitian}

Subjek dalam penelitian ini adalah mahasiswa prodi PGMI Fakultas Tarbiyah UIN Sunan Kalijaga yang berusia antara 20-22 tahun, baik laki-laki maupun perempuan, bersedia mengikuti eksperimen, dan memiliki SRL rendah dan sedang (Mengacu pada hasil penelitian sebelumnya, sebagai preliminary, Latipah, 2009). Penentuan subjek kedalam kelompok eksperimen dan kontrol dilakukan dengan cara menyediakan gulungan-gulungan kertas kecil yang berisi huruf $\mathrm{A}$ dan $\mathrm{B}$, dimana huruf A adalah kelompok eksperimen dan B adalah kelompok kontrol. Subjek yang mendapat gulungan kertas huruf A, masuk pada kelompok eksperimen dan subjek yang mendapat gulungan kertas huruf $\mathrm{B}$, masuk pada kelompok kontrol. Masing-masing kelompok berjumlah 40 orang. Proses pelaksanaan eksperimen dapat dilihat pada Tabel 1.

Instrumen yang digunakan dalam pengumpulan data adalah skala self regulated learning dan modul experiential learning digunakan sebagai pedoman dalam menerapkan strategi pembelajaran eksperiensial. Data yang terkumpul dianalisis dengan teknik analisis multivariat. 
Tabel 1.

Pelaksanaan Eksperimen

\begin{tabular}{|c|c|c|}
\hline No & Kegiatan & Keterangan \\
\hline 1. & $\begin{array}{l}\text { Seleksi (penentuan) kelas subjek eksperimen } \\
\& \text { kontrol. }\end{array}$ & Dilakukan menjelang perkuliahan. \\
\hline 2 & $\begin{array}{l}\text { Pretes SRL siklus } 1 \\
\text { Waktu: } 1 \text { x15 menit }\end{array}$ & $\begin{array}{l}\text { Subjek diminta mengisi skala SRL pada materi } 1 \\
\text { (mata kuliah matematika) (pertemuan } 1 \text { ) }\end{array}$ \\
\hline 3 & $\begin{array}{l}\text { Pemberian perlakuan siklus } 1 \\
\text { Waktu: } 11 \text { pertemuan x } 100 \text { menit }\end{array}$ & $\begin{array}{l}\text { Penerapan tahapan-tahapan EL dalam } \\
\text { pembelajaran (pertemuan } 1 \text { s.d } 11)\end{array}$ \\
\hline 4 & $\begin{array}{l}\text { Postes SRL siklus } 1 \\
\text { Waktu: } 1 \text { x } 15 \text { menit }\end{array}$ & $\begin{array}{l}\text { Subjek diminta mengisi skala SRL pada materi } 1 \\
\text { (pertemuan 11) }\end{array}$ \\
\hline 5 & $\begin{array}{l}\text { Pretes SRL siklus } 2 \\
\text { Waktu: } 1 \times 15 \text { menit }\end{array}$ & $\begin{array}{l}\text { Subjek diminta mengisi skala SRL pada materi } 2 \\
\text { (pertemuan 12) }\end{array}$ \\
\hline 6 & $\begin{array}{l}\text { Pemberian perlakuan siklus } 2 \\
\text { Waktu: } 10 \text { pertemuan x } 100 \text { menit }\end{array}$ & $\begin{array}{l}\text { Penerapan tahapan-tahapan EL dalam } \\
\text { pembelajaran materi } 2 \text { (pertemuan } 12 \text { s.d } 21)\end{array}$ \\
\hline 7 & $\begin{array}{l}\text { Postes SRL siklus } 2 \\
\text { Waktu: } 1 \text { x } 15 \text { menit }\end{array}$ & $\begin{array}{l}\text { Subjek diminta mengisi skala SRL pada materi } 2 \\
\text { (pertemuan 21) }\end{array}$ \\
\hline 8 & $\begin{array}{l}\text { Pretes SRL siklus } 3 \\
\text { Waktu: } 1 \times 15 \text { menit }\end{array}$ & $\begin{array}{l}\text { Subjek diminta mengisi skala SRL pada materi } 3 \\
\text { (pertemuan 22) }\end{array}$ \\
\hline 9 & $\begin{array}{l}\text { Pemberian perlakuan siklus } 3 \\
\text { Waktu: } 7 \text { pertemuan x } 100 \text { menit }\end{array}$ & $\begin{array}{l}\text { Materi: penerapan } 4 \text { tahapan EL dalam } \\
\text { pembelajaran materi } 3 \text { (pertemuan } 22 \text { s.d 28) }\end{array}$ \\
\hline 10 & $\begin{array}{l}\text { Postes SRL siklus } 3 \\
\text { Waktu: } 1 \text { x } 15 \text { menit }\end{array}$ & $\begin{array}{l}\text { Subjek diminta mengisi skala SRL pada materi } \\
3 \text { (pertemuan 28) }\end{array}$ \\
\hline 11 & $\begin{array}{l}\text { Penerapan SRL } \\
\text { Waktu: } 14 \text { pertemuan x } 100 \text { menit (setengah } \\
\text { semester) }\end{array}$ & $\begin{array}{l}\text { Subjek menerapkan SRL dalam pembelajaran } \\
\text { berikutnya }\end{array}$ \\
\hline
\end{tabular}

\section{Hasil Dan Pembahasan}

Hasil menunjukkan bahwa terdapat perbedaan SRL yang sangat signifikan antara kelompok eksperimen dan kontrol $(\mathrm{F}=18,213$ dan $\mathrm{p}=<0,01)$. Dimensi-dimensi SRL yang telah dipengaruhi oleh strategi experiential learning sebagaimana dirangkum pada Tabel 2.

Tabel 2

Rangkuman Uji Efek Antar Subjek

\begin{tabular}{lllllll}
\hline \multicolumn{1}{c}{ Sumber } & \multicolumn{1}{c}{ Variabel } & $\begin{array}{c}\text { Jumlah } \\
\text { Kuadrat }\end{array}$ & df & $\begin{array}{c}\text { Rerata } \\
\text { Kuadrat }\end{array}$ & F & Sig. \\
\hline Strategi & Motivasi Belajar & 60,516 & 1 & 60,516 & 18,308 & 0,000 \\
Pembelajaran & Strategi Belajar Kognitif & 59,280 & 1 & 59,280 & 15,427 & 0,000 \\
& Regulasi Metakognitif & 32,263 & 1 & 32,263 & 9,859 & 0,002 \\
& Kelola Sumber Daya & 21,811 & 1 & 21,811 & 10,725 & 0,002 \\
\hline
\end{tabular}

Mengacu Tabel 2, terdapat perbedaan motivasi belajar $(\mathrm{F}=18,308 ; \mathrm{p}<0,001)$, strategi belajar kognitif $(\mathrm{F}=15,427 ; \mathrm{p}<0,01)$, regulasi metakognitif $(\mathrm{F}=9,859 ; \mathrm{p}<0,01)$, dan kelola sumber daya $(\mathrm{F}=10,725 ; \mathrm{p}<=0,01)$ yang signifikan antara kelompok eksperimen dan kontrol. Ini menunjukkan bahwa strategi experiential learning berpengaruh terhadap motivasi belajar, strategi belajar kognitif, regulasi metakognitif, dan kelola sumber daya. Rerata SRL dan dimensi-dimensinya ditunjukkan pada Gambar 1. Rerata SRL dan dimensi-dimensinya (motivasi belajar, strategi belajar kognitif, regulasi metakognitif, dan kelola sumber daya) pada kelompok eksperimen lebih tinggi daripada kelompok kontrol. Rerata pada kelompok eksperimen yang lebih tinggi ini 
menunjukkan bahwa strategi experiential learning telah meningkatkan SRL dan dimensi-dimensinya. Sementara kelompok yang diberi strategi biasa mengalami peningkatan SRL namun peningkatan tersebut lebih rendah dibandingkan dengan kelompok yang diberi strategi experiential learning.

Adanya perbedaan SRL dan dimensi-dimensinya ini sesuai dengan temuan Kramarski (2006), Sungur \& Tekaya (2006), Huynh (2008), Darmiany (2009), Kristiyani (2010), Ruseno \& Titin (2010) bahwa strategi experiential learning mampu meningkatkan SRL dan dimensi-dimensinya. Ini bisa dijelaskan melalui beberapa penjelasan berikut. Pertama, tahapan strategi experiential learning yang disebut sebagai tahap refleksi. Ini merupakan tahapan kritis dalam strategi experiential learning (Kolb, 1984). Melalui refleksi mahasiswa dapat mengungkapkan kembali pengalamanpengalaman yang telah dimiliki sebagai proses untuk memadukan pengalaman dengan pengetahuan baru yang diperoleh di dalam kelas. Dalam pembelajaran, mahasiswa dibiasakan melakukan tahap refleksi untuk memikirkan kembali pengalamanpengalaman yang telah dimiliki terkait dengan pokok bahasan yang sedang dipelajari. Pengalaman-pengalaman mahasiswa tentang pokok bahasan tertentu ternyata selalu beragam. Mereka memiliki sudut pandang yang berbeda-beda tentang sebuah peristiwa. Menurut Ormrod (2008) hal tersebut disebabkan adanya proses unik yang berbeda dari setiap individu dalam memahami sebuah peristiwa.

Keragaman sudut pandang terkait materi yang sedang dipelajari dikemukakan di dalam kelas. Sejalan dengan teori kognitif sosial tentang proses konstruksi pengetahuan bahwa proses konstruksi pengetahuan dapat dilakukan dengan adanya interaksi sosial. Interaksi sosial di dalam kelas diwujudkan dalam bentuk adanya diskusi untuk berbagi informasi antara satu mahasiswa dengan mahasiswa lainnnya dalam kelompokkelompok kecil. Pemaduan inilah yang akhirnya menjadi pengetahuan baru bagi mahasiswa.

Kedua, proses konstruksi materi. Pengonstruksian pengetahuan dilakukan sendiri oleh mahasiswa. Konstruksi didasarkan atas pilihan dan minat-minat pribadinya (Roberts, 2010). Dengan kata lain, mahasiswa mengonstruksi pengetahuan barunya dengan menggunakan pemahaman dan istilah/bahasa sendiri. Asumsinya, dengan menggunakan bahasanya sendiri, mahasiswa dapat lebih mudah memahaminya. Dengan pemahaman baru tersebut, mahasiswa dapat menerapkan dalam situasi lain yang berbeda. Ketiga, dalam experiential learning mahasiswa mendapatkan banyak pengalaman belajar melalui latihan, praktek, simulasi, dan bermain peran. Dalam proses tersebut mahasiswa melakukan pengamatan pengalaman belajarnya sendiri atau pengalaman teman-temannya. Hasil dari pengamatan tersebut selanjutnya direfleksikan, yaitu mengungkapkan kembali hasil pengamatannya tersebut. Proses refleksi pada akhirnya menggiring mereka untuk mampu menyusun atau mengkonstruk sendiri hasil pembelajarannya. Mahasiswa juga diajak untuk mampu mengimplementasikan hasil konstruksinya dalam kehidupan nyata sehari-hari atau dalam bentuk penyelesaian masalah (problem solving).

Self regulated learning berkembang dari kesempatan mengamati orang lain (Zimmerman, 2004). Dalam proses pembelajaran sebagaimana yang telah dilakukan dalam penelitian eksperimen ini, kegiatan pembelajaran dilakukan dengan cara meminta mahasiswa untuk mengamati apa yang dilakukan (disimulasikan, didemonstrasikan) oleh teman-temannya di depan kelas. Sebagai permisalan dalam pembelajaran bilangan pecahan, mahasiswa diminta untuk memeragakan bagaimana cara melipat kertas sesuai dengan bilangan pecahan tertentu. Dalam proses tersebut, sebelum maju ke depan untuk 
mendemonstrasikan, mahasiswa berdiskusi dalam kelompok kecil masing-masing, baru didemonstrasikan di depan kelas dan kelompok lain diminta untuk mengamati presentasi demonstrasi temannya. Dalam proses mengamati tersebut mahasiswa akan terbantu untuk belajar bagaimana menetapkan tujuan, bagaimana menjaga agar perhatian mereka tetap fokus pada tugas belajar, bagaimana menggunakan strategi belajar yang efektif, bagaimana memonitor kemajuan belajar, dan sebagainya. Dengan mengamati apa yang dilakukan teman ketika demonstrasi, mahasiswa juga akan mempelajari tentang kekurangan dan kelebihan yang dipresentasikan temannya, sehingga dia dapat merencanakan apa yang seharusnya ia lakukan ketika dia juga presentasi. Selain itu hal tersebut akan melatih mahasiswa untuk dapat memikirkan strategi apa yang perlu dia pilih dalam presentasi, adakah media yang perlu dia tambahkan atau maksimalkan untuk memberi penguatan materi, dan seterusnya. Pada kondisi tersebut mahasiswa semakin menyadari akan tanggung jawab yang harus dipikulnya. Hal tersebut semakin mempertajam bahwa strategi pembelajaran eksperiensial mampu meningkatkan belajar berdasar regulasi diri, dalam hal ini meningkatkan tanggung jawab dan performa akademik mahasiswa.

Penelitian Huynh (2009), Slazak \& Zurick (2009), Grouws \& Cebulla (2001), Shachar \& Sharan (1994) menunjukkan bahwa experiential learning memungkinkan seseorang lebih tertarik pada materi pembelajaran. Ketertarikan ini akan menjadi dorongan yang kuat untuk meningkatkan semangat belajar mahasiswa, sebagaimana dikatakan (Syah, 2010) bahwa rasa tertarik (minat) dapat mendorong seseorang untuk melakukan sesuatu. Mahasiswa pada kelompok eksperimen mendapat banyak pengalaman belajar melalui berbagai kegiatan seperti simulasi, demonstrasi, latihanlatihan, permainan, dan sebagainya. Ini mengantarkan mereka untuk bergerak secara energik atau menjadi pendorong kuat dalam mencapai tujuan yang telah ditetapkan. Pengalaman-pengalaman dalam pembelajaran telah memenuhi kebutuhan mahasiswa yakni kebutuhan akan rasa ingin tahu terhadap materi yang disampaikan. Ini sebagaimana dijelaskan Ormrod (2008) bahwa kegiatan praktek, eksperimen, dan sejenisnya dalam pembelajaran akan memenuhi kebutuhan, motif, dan hasrat pembelajar dalam pembelajaran. Pengalaman-pengalaman pembelajaran juga menjadi daya tarik tersendiri bagi mahasiswa melalui beragam media yang sangat menarik dan beragam permainan yang dihadirkan. Ini selaras dengan temuan hasil penelitian Sigit (2012) tentang efek penggunaan media pembelajaran terhadap motivasi dan prestasi belajar para mahasiswa calon guru agama.

Setiap mahasiswa termotivasi dalam suatu cara tertentu (Ormrod, 2008). Mahasiswa dapat termotivasi melalui ketertarikannya pada materi kuliah dan mengerjakan tugas yang menantang, berpartisipasi secara aktif dalam diskusi, dan mendapatkan nilai tinggi dalam tugas-tugas yang diberikan. Hal ini menunjukkan bahwa mahasiswa punya ketertarikan terhadap masalah akademik. Motivasi tidak selalu merupakan sesuatu yang dibawa oleh seseorang (mahasiswa) ke kampus. Motivasi juga dapat muncul dari kondisi lingkungan di kampus (Paris \& Turner, 1994), termasuk dalam hal ini adalah bagaimana dosen menggunakan strategi dalam pembelajaran di kelas. Strategi experiential learning menuntut dosen untuk menghadirkan pengalamanpengalaman belajar melalui berbagai kegiatan belajar seperti simulasi, demonstrasi, diskusi, bermain peran, bahkan permainan. Kegiatan pembelajaran seperti ini membuat dosen perlu merancang pembelajaran sedemikian rupa, mulai dari penetapan tujuan pembelajaran, langkah-langkah pembelajaran, media dan alat pembelajaran, sampai kepada penilaian pembelajaran. Perancangan tersebut membuat dosen merasa antusias 
dan optimis bahwa pembelajarannya akan membawa pada kesuksesan mahasiswa secara akademik (dan non-akademik) dan dosen memiliki harapan dan atribusi yang tinggi kepada mahasiswa (Woolfolk, 2008).

Temuan Vandsburger (2010), Wurdinger \& Paxton (2003), Shachar \& Sharan (1994) bahwa experiential learning memungkinkan mahasiswa untuk menggunakan berbagai strategi belajar kognitif, yaitu strategi yang bersifat fleksibel, menyesuaikan dengan kebutuhan materi pembelajaran. Mahasiswa kelompok eksperimen mendapatkan banyak tugas belajar secara tepat. Tugas yang diperoleh mahasiswa tidak sekedar tugas-tugas yang menuntut mereka untuk mempelajari dan mengembalikan (learn and return) kata-kata dalam teks atau penjelasan dosen dengan sama persis saja, yaitu bila hafal mahasiswa akan mendapat hadiah (nilai), sehingga mahasiswa akan menggunakan strategi-strategi andalannya seperti latihan terdistribusi (distributed practice) dan mnemonic. Dosen memberikan tugas-tugas kepada mahasiswa untuk memahami atau bahkan menerapkan dalam kehidupan nyata sehari-hari yaitu terutama dalam pembelajaran, yang menuntut mahasiswa untuk menggunakan strategi belajar yang lebih kompleks lagi. Strategi-strategi yang digunakan mahasiswapun tidak sekedar menghafal dan mnemonic, lebih dari itu mereka menggunakan strategi-strategi lain seperti bagaimana mengidentifikasi informasi penting, memanggil pengetahuan awal yang relevan, membuat catatan, mengorganisasikan informasi, mengelaborasi informasi secara sengaja, membuat ringkasan, sampai kepada memonitor (monitoring) pemahaman.

Temuan para ahli seperti Teranishi (2004), Warren dkk (2008), Rogoff dkk. (2003), bahwa experiential learning memungkinkan mahasiswa untuk melakukan regulasi metakognitif dalam pembelajarannya. Mahasiswa pada kelompok eksperimen melakukan perencanaan (planning), pengontrolan (monitoring), dan penilaian (evaluating) (Zimmerman \& Martinez-Pons, 1998) terhadap proses pembelajarannya. Dalam perencanaan, mahasiswa membuat rencana-rencana pembelajaran yang akan dilakukan. Pembuatan rencana dilakukan mahasiswa setiap setelah penyampaian tujuan pembelajaran yaitu pada setiap awal pembelajaran. Pertanyaan yang diajukan kepada mahasiswa untuk menggali rencana pembelajaran ini adalah 'dengan tujuan pembelajaran sebagaimana telah disampaikan dosen, apa target belajar Anda, dan apa yang akan Anda lakukan untuk mencapai target-taget tersebut'. Berdasar pertanyaan tersebut, mahasiswa nampak dapat mengemukakan target-target pembelajaran dengan sangat jelas, dan rencana-rencana yang akan mereka lakukanpun nampak sangat logis dan realistis. Pengontrolan mahasiswa atas proses belajarnya dilakukan dengan cara mengisi lembar kegiatan pembelajaran yang telah diberikan. Berdasar lembar tersebut diperoleh bahwa mahasiswa senantiasa mengecek tentang strategi pembelajaran yang digunakan, waktu yang digunakan untuk mengerjakan tugas-tugas matematika, hal yang dilakukan ketika menemui kesulitas, tugas yang memerlukan perhatian penuh dan yang tidak memerlukan perhatian penuh, dan sebagainya. Dengan pengontrolan seperti ini mahasiswa merasa dapat melakukan perubahan di tengah-tengah ketika ditemukan bahwa strategi yang telah digunakan kurang sesuai, mahasiswa meminta bantuan kepada orang yang tidak tepat, kurangnya waktu yang disisihkan untuk mengerjakan tugas-tugas.

Temuan para ahli seperti Kirschner, dkk. (2009), Russell (2006), Rieber \& Clinton (2010), Ramli (2010) bahwa experiential learning memungkinkan mahasiswa untuk mengelola sumber dayanya (waktu dan lingkungan) untuk meningkatkan pembelajarannya. Mahasiswa pada kelompok eksperimen terbiasa melakukan 
pengelolaan waktu dan lingkungan serta penggunaan sumber dayanya untuk pembelajaran. Mahasiswa secara mandiri menata alat-alat atau bahan-bahan pembelajaran dengan cara-cara yang mendorong interaksi mereka dengan temantemannya maupun interaksi antara mereka dengan dosen. Untuk membiasakan dan memudahkan mahasiswa berinteraksi, tempat duduk sangat jarang ditata dengan posisi mahasiswa berhadapan langsung dengan dosen. Tempat duduk seringkali disusun dengan cara-cara yang dapat meminimalkan kemungkinan terjadinya perilaku-perilaku yang tidak diharapkan, yang tidak ada kaitannya dengan materi yang sedang dibahas. Tempat duduk mahasiswa disusun dengan pola lalu lintas yang memungkinkan mahasiswa bergerak di ruangan tanpa menganggu teman lainnya. Media dan alat-alat peraga pembelajaran seringkali dijauhkan dari tempat yang mudah dijangkau dengan tujuan untuk menjaga konsentrasi mahasiswa.

Hubungan antara dosen dengan mahasiswa terjalin secara kondusif dan suportif. Suasana kondusif dan suportif merupakan kontributor penting bagi iklim kelas secara menyeluruh. Hubungan kondusif dan suportif merupakan lingkungan psikologis umum yang mewarnai interaksi pembelajaran (Ormrod, 2008; Passer, 2009). Dalam membangun lingkungan belajar yang kondusif dan suportif dilakukan dosen dengan cara membangun suasana yang berorientasi tujuan, namun tidak menakutkan (kaku). Dosen menekankan bahwa meski hubungan baik antara dia dan mahasiswanya sangat penting namun dosen menyadari bahwa dia harus mempertahankan suasana yang menyerupai bisnis di kelas. Suasana bisnis di kelas dilakukan dengan cara meminta mahasiswa untuk bertanggung jawab dalam mencapai tujuan-tujuan pembelajaran tanpa harus diawasi terus. Ini dapat terlihat dari penulisan target-target pembelajaran yang rutin diminta setiap kali pembelajaran.

Keterbatasan dari penelitian ini adalah bahwa salah satu tahapan dalam strategi experiential learning adalah adanya refleksi. Untuk melakukan refleksi dibutuhkan waktu cukup panjang agar mahasiswa dapat mengungkapkan kembali proses pembelajaran dengan mendalam. Namun demikian, sehubungan waktu pembelajaran terbatas (100 menit dalam satu kali tatap muka), seringkali waktu untuk melakukan refleksi terasa sangat singkat sehingga mahasiswa melakukan refleksi atas proses pembelajaran yang dilakukannya, kurang mendalam. Singkatnya, keterbatasan penelitian ini adalah kurangnya waktu untuk melakukan proses refleksi dalam pembelajaran.

\section{Simpulan}

Berdasar beberapa temuan di atas, beberapa poin penting yang dapat disimpulkan bahwa strategi experiential learning berpengaruh terhadap self regulated learning mahasiswa PGMI berdasar adanya perbedaan SRL dan dimensi-dimensinya (motivasi belajar, strategi belajar kognitif, regulasi metakognitif, dan keola sumber daya) yang sangat siginifikan pada kelompok eksperimen dan kelompok kontrol. Peningkatkan self regulated learning mahasiswa dapat dilakukan dengan cara menggunakan strategi experiential learning dalam pembelajaran. 


\section{Daftar Pustaka}

Arjanggi, R. \& Suprihatin, T. (2010). Efektivitas metode pembelajaran tutor teman sebaya terhadap belajar berdasar regulasi diri rendah. Paper. Dipresentasikan dalam Konferensi Nasional Psikologi Eksperimen di UGM, Yogyakarta.

Bandura, A. (1997). Self efficacy: the exercises of control. New York: Freeman.

Barron, K. E., \& Harackiewicz (2001). Achievement Goals and Optimal Motivation. Testing Multiple Goals Models. Journal of Personality and Social Psychology, 80 (5), 706-722.

Bruning, R. H., Schraw, G. J., Norby, M. M., \& Ronning, R. R. (2004). Cognitive Psychology and Instruction ( ${ }^{\text {rd }}$ Ed). Columbus, $\mathrm{OH}$ : Merrill.

Bruning, R. H., Schraw, G. J., Norby, M. M., \& Ronning, R. R. (2004). Cognitive Psychology and Instruction ( $3^{\text {rd }}$ Ed). Columbus, OH: Merrill.

Darmiany (2009). Penerapan pembelajaran eksperiensial dalam mengembangkan self regulated learning. Disertasi (Tidak diterbitkan). Malang: Univeristas Negeri Malang.

Davis, D. K. (2009). What's wrong with character education? American Journal of Education. 110 (1), 141-154.

De Kock, A., Sleegers, P., \& Voeten, J., M. (2004). New learning and the classification of learning environments in secondary education. Review of Educational Research, 74, 141-170.

Dweck, C. S. (1999), dalam Steele-Johnson, D. S. (2000). Goal Orientation and Task Demand Effects on Motivation, Affect, and Performance. Journal of Applied Psychology, 25 (3), 724-738.

Elliot, S. N., Kratochwill, T. R., Littlefield, J., \& Travers, J. F. (1999). Educational Psychology: Effective Teaching Effective Learning. New York: McGraw-Hill Book Company.

Grouws, Douglas, A. \& Cebulla, Kristin, J. (2001). Improving Students Achievement in Mathematics. Diunduh dari http://www.ibe.unesco.org. tanggal 10 Februari 2012.

Howard-Rose, D., \& Winne, P. H. (1993). Measuring Concept and Sets of Cognitive Process in Self Regulated Learning. Journal of Educational Psychology, 85 (4), 591-523.

Huynh, D., Haines, S. T., Plaza, C. M., Sturpe, D. A., Williams, G., de Britner, M. A. R., \& Roffman, D. S. (2009). The impact of advanced pharmacy practice experiences on students' readiness for self regulated learning. American Journal of Pharmaceutical Education, 73 (4), 1-8.

Kirschner, P. A., Sweller, J., \& Clark, R. E. (2006). Why minimal guidance does not work: An analysis of the failure of constructivist, discovery, problembased, experiential, and inquiry-based teaching. Educational Psychologist, 41 (2), 7586. 
Knowles, Malcolm, S. (1970). The Modern Practics of Adult Education, Andragogy versus Pedagogy. New York: Association Press.

Kolb, A., \& Kolb, D. A. (1999). Bibliography of Research on Experiential Learning Theory and The Learning Style Inventory. Department of Organizational Behavior, Weatherhead School of Management, Case Western Reserve University, Cleveland, $\mathrm{OH}$.

Kolb, D. A. (1984). Experiential Learning: Experience as the Source of Learning and Development. Englewood Cliffs, New Jersey: Prentice-Hall.

Kramarski, B., and Mizrachi, N. (2006). Online Discussion and Self-Regulated Learning: Effects of Instructional Methods on Mathematical Literacy. The Journal of Educational Research, 99 (4), 218-230.

Kristiyani, T. (2010). Penerapan classroom assessment techniques (CATs) dalam perkuliahan untuk meningkatkan self reguated learning serta prestasi belajar statistik II pada mahasiswa psikologi. Paper. Dipresentasikan dalam Konferensi Nasional Psikologi Eksperimen di UGM, Yogyakarta.

Latipah, E. (2009). Belajar berdasar regulasi diri pada mahasiswa prodi PGMI Fakultas Tarbiyah dan Keguruan UIN Sunan Kalijaga. Jurnal al-Bidayah, 1 (1), 267-271.

Laurillard, D. (2002). Rethinking University Teaching-2nd Edition. New York: Routledge Falmer.

Marcus, N., Cooper, M., \& Sweller, J. (1996). Understanding Instructions. Journal of Education Psychology, 88, 49-63.

McCombs, B. L. \& Marzano, R. J. (1990). Putting the Self in Self Regulated Learning: the Self as Agent in Integrating Skill and Will. Educational Psychologist, 25, 5170.

Meichanbaum, D., Burland, S., Gruson, L., \& Cameron, R. (1985). Metacognitive Assessment. Dalam S. Yussen (Ed.). The Growth of Reflection in Children (hlm. 1-30). Orlando, FL: Academic Press.

Metcalfe, J. \& Shimamura, A. P. (1994). Metacognition: Knowledge about Knowing. Cambridge, MA: MIT Press.

Murphy, P. K. \& Alexander, P. A. (2000). A Motivated Exploration of Motivation Terminology. Contemporary Educational Psychology, 25, 3-53.

Nelson, T. O. (1996). Consciousness and metacognition. American Psychologist, 51, 102-116.

Ormrod, J. E. (2008). Educational Psychology Developing Learners Jilid 1 (6 $6^{\text {th }}$ ed). New Jersey: Prentice-Hall, Inc.

Paris, S. C. \& Turner, L. R. (1994). Becoming Reflective Students and Teachers: With Portofolios and Authentic Assessment. Washington, DC: American Psychological Association.

Passer, M. W. \& Smith, R. E. (2009). Psychology The Science of Mind and Behavior. Toronto: McGraw Hill International Edition. 
Purdie, N. \& Hattie, J. (1996). Cultural Differences in the Use of Strategies for SelfRegulated Learning. American Educational Research Association, 33(4), 845871.

Ramli, R. (2010). Technology Enhanced Learning: Fostering Cooperative Learning Through the Integration of Online Communication as Part of Teaching and Learning Experience. World Academy of Science, Engineering and Technology, 69, 611-614.

Rieber L. P. \& Clinton, G. (2010). The Studio experience at the University of Georgia: an example of constructionist learning for adults. Education Tech Research Development Article, 58, 755-780.

Roberts, S. (2010). Reflection on life experience as an aid to deeper learning. Nursing Older People, 22 (10), 33-37.

Rogoff, B., Paradise, R., Meija-Arauz, R., Correa-Chavez, M., \& Angelillo, C. (2003). Firsthand learning through intent participation. Annual Review of Psychology, 54, 175-203.

Rosiana, D., Sumaryanti, I.U., Diantina, F.P. (2010). Strategi peningkatan prestasi belajar melalui pembinaan terpadu berbasis self regulated learning pada mahasiswa berprestasi rendah. Paper. Dipresentasikan dalam Konferensi Nasional Psikologi Eksperimen di UGM, Yogyakarta.

Ruseno A., \& Titin S. (2010). Efektivitas metode pembelajaran tutor teman sebaya terhadap belajar berdasar regulasi diri. Laporan Penelitian. Disampaikan sebagai Materi Parallel Session dalam Konferensi Psikologi Eksperimen. Yogyakarta: Fakultas Psikologi UGM.

Russell, K. (2006). Publishing to the choir or digging deep: Implications of a snapshot of experiential education research. Journal of Experiential Education, 28(3), 243-247.

Santrock, J. W. (1997). Life Span Development. Toronto: Brown \& Benchmark.

Saskatchewan Education, 1988. Understanding The Common Essential Learnings: A Handbook for Teachers. Regina, SK: Saskatchewan Education.

Sawitri, D.R. \& Ariati, J. (2010). Malas, ngantuk, bosan: hambatan mahasiswa untuk mencapai indeks prestasi tinggi. Paper. Dipresentasikan dalam Konferensi Nasional dan Workshop Asosiasi Psikologi Pendidikan Indonesia. Malang: 16 \& 17 Oktober 2010.

Seamen, J. (2008). Experience, Reflect, Critique: The End of the "Learning Cycles" Era. Journal of Experiential Education, 31 (1), 3-18.

Shachar, H. \& Sharan, S. (1994). Talking, Relating, and Achieving: Effects of Experiential Learning and Whole-Class Instruction. Cognitive and Instruction, 12, 313-353.

Sigit, P. (2012). Peningkatan prestasi pembelajaran sains melalui optimalisasi media visual. Laporan Penelitian. Yogyakarta: Prodi PGMI Fakultas Tarbiyah dan Keguruan UIN Sunan Kalijaga. 
Slavin, R. E. (2009). Educational Psychology. Engleewood Cliffs, New Jersey: Prentice-Hall, Inc.

Slavin, R. E. (2009). Educational Psychology. Engleewood Cliffs, New Jersey: Prentice-Hall, Inc.

Slazak, E. M. \& Zurick, G. M. (2009). Practice-based learning experience to develop residents as a clinical faculty members. Journal of Health System Pharmacy, 66 (1), 1224-1227.

Smith, D. D. (2006). Introduction to Special Education: Teaching in an Age of Opportunity $\left(5^{\text {th }}\right.$ ed). Boston: Allyn and Bacon.

Smith, P. A. (2001). Understanding Self Regulated Learning and Its Implications for Accounting Aducators and Research. Issues in Accounting Education, 16 (4), 663-667.

Sunawan (2003). Pengelolaan Diri dalam Belajar untuk Meningkatkan Prestasi Belajar Matematika Pada Siswa Sekolah Mennegah Umum (SMU). Tesis (tidak diterbitkan). Yogyakarta: Program Pascasarjana UGM.

Sungur S. \& Tekkaya C. (2006). Effects of Problem-Based Learning and Traditional Instruction on Self-Regulated Learning. The Journal of Educational Research, 99 (5), 307-317.

Syah, M. (2010). Psikologi Pendidikan dengan Pendekatan Baru. Bandung: Rosdakarya.

Teranishi, C. S. (2004). Impact of Experiential Learning on Latino College Students' Identity, Relationships, and Connectedness to Community. Journal of Teaching in Social Work, 30, 200-215.

Valle, A., Núñez, José C., Ramón G. C., Julio Antonio González-Pienda, Susana R., Pedro R.,María A. Muñoz-Cadavid (2008). Self-regulated profiles and academic achievement. Psicothema, 20 (4), 724-731.

Vandsburger, E., Duncan-Daston, R., Akerson, E., \& Dillon, T. (2010). The Effects of Poverty Simulation, an Experiential Learning Modality, On Students' Understanding of Life in Poverty. Journal of Teaching in Social Work, 30, 300316.

Warren, J., Roberts, K., McGriff, D., Morris, \& Lay-nah B. (2008). Assessing the Impact of Experiential Learning on Attitudes toward Change, Addictions and Addicts: The Addict, the Pig and the Coin. Experiential Learning, Addictions and Attitude Change, 4, 1-24.

Woolfolk, A. (2008). Educational Psychology Active Learning Edition-Tenth Edition. Boston: Allyn \& Bacon.

Wurdinger, S. \& Paxton, T. (2003). Using multiple levels of experience to romote autonomy in adventure education students. Journal of Adventure Education and Outdoor Learning, 3(1), 41- 48.

Zimmerman, B. J. \& Kitsantas, A. (1999). Acquiring writing revision skill: Shifting from process to outcome self regulatory goals. Journal of Educational Psychology, 91 (2), 241-250. 
Zimmerman, B. J. \& Martinez-Pons, M. (1990). Student differences in self regulated learning: Relating grade, sex, and giftedness to self efficacy and strategy use. Journal of Educational Psychology, 82, 51-59.

Zimmerman, B. J. \& Martinez-Pons, M. (1998). Construct Validation of Strategy Model of Student Self Regulated Learning. Journal of Educational Psychology, 80 (2), 284-290.

Zimmerman, B. J. (2002). Becoming a Self Regulated Learner: An Overview. Theory into Practice, 41, 64-70.

Zimmerman, B. J. \& Martinez-Pons, M. (2001). Students differences in self regulated learning: relating grade, sex, and giftedness to self efficacy and strategy use. Journal of Educational Psychology. 82 (1), 51-59. 